\title{
Indigenous and other Australians since 1901: A conversation between Professor Tim Rowse and Dr Miranda Johnson
}

\author{
Miranda Johnson and Tim Rowse
}

Tim Rowse's book, Indigenous and Other Australians Since 1901 (2017), raises timely questions about the writing of Aboriginal history, as well as offering insights into contemporary political debates. In this conversation, conducted via email, we examine some of the book's arguments, the evidence drawn on to make them and why these interventions are necessary today. In the introduction to the book, Rowse draws attention to W.E.H. Stanner's hope for telling the 'the story ... of the unacknowledged relations between two racial groups within a single field of life. ${ }^{1}$ He shows why this was and continues to be so difficult in terms of identity, territorial control and jurisdictional practice. In Australia, indigeneity does not mean one thing, and its meaning has changed and become increasingly plural over time; for much of the twentieth century there were really two Australias - north and south - that were represented and governed differently; and two sovereignties - one kin-based, the other state-based - that have posed considerable challenges to each other, right up to the present. This argument serves as the jumping-off point for the conversation.

\section{MJ: Why these two groups, 'Indigenous' and 'Other Australians'? Who do you imagine, in the context of this book, comprises these two groups?}

TR: The binary Indigenous/non-Indigenous (or 'other Australians') has been around as a framework for official statistics since 1969, and it has become the basis of an important notion of 'social justice' (Closing the Gap). The binary has become

1 Quoted in Rowse 2017: 4. 
central to Australians' national imaginary, partly through the state's and civil society organisations' promotion of 'reconciliation' since 1991. Recall that in the Preamble to the Council for Aboriginal Reconciliation Act 1991, we find the affirmations that:

(a) Australia was occupied by Aborigines and Torres Strait Islanders who had settled for thousands of years, before British settlement at Sydney Cove on 26 January 1788; and

(b) many Aborigines and Torres Strait Islanders suffered dispossession and dispersal from their traditional lands by the British Crown; and

(c) to date, there has been no formal process of reconciliation between Aborigines and Torres Strait Islanders and other Australians [my emphasis].

So the binary has currency as part of our civic vocabulary.

'Indigenous' comprises 'Aboriginal people' and 'Torres Strait Islanders'. 'Other Australians' is, of course, a very heterogeneous category. In my book, I have not considered distinctions among 'other Australians' that are undoubtedly important: of class, of sex, of ethnic identity, of Australian-born and overseas-born, of Anglophone and Non-English Speaking Background (NESB). A lot could be said about the different ways that these various categories of non-Indigenous Australian have been oriented towards their settler status. I have not gone into these differences at all in the book, though I am giving them some attention in my work on the Australian Cultural Fields project. ${ }^{2}$ However, I have devoted a lot of attention to three axes of difference among Indigenous Australians: region, sex and class. I have tried to give a textured account of 'Indigenous Australia' by highlighting the historical emergence of these distinctions among them.

\section{MJ: And why the period, 'since 1901'? Is the twentieth-century story, post-Federation, quite distinct from that of the nineteenth?}

TR: Before 1901, six colonies acted independently of each other, though not in ignorance of each other. The settler colonial state substantially changed its internal dynamics in 1901, in that six colonies formed a national level of government. The story of the state's dealings with Indigenous Australians is from that moment partly a story of intergovernmental relationships. My earlier work on 'assimilation' had taught me that they were important. The act of federation, driven powerfully by 'white Australia' nationalism, also raised the question of the non-white populations of 'north' Australia. How was the 'south' (where the visions of federation flourished) to incorporate this 'multicultural' north (a question studied by Henry Reynolds, Regina Ganter, Gary Lee, Julia Martinez and Adrian Vickers)?

2 Australian Cultural Fields: National and Transnational Dynamics, www.westernsydney.edu.au/ACF (accessed 14 August 2018). 
The year 1901 also saw the inception of the Australian constitution, which contained the phrase 'aboriginal native'; that term now had to be operationally defined a much tougher challenge than anyone then imagined, I think I have shown. I chose Alfred Deakin as the representative historical agent who made Federation significant in 'Indigenous affairs', because he did three things that defined the cultural and geopolitical outlook of the federation project. In 1902, he defined 'aboriginal native' for constitutional law. In 1905, he published (anonymously) a concise prospectus of the extension of the rule of law over the entire continent, acknowledging the relative weakness of the state in the north. In 1910, speaking on the Commonwealth's takeover of the Northern Territory, he again projected nationhood in continental terms, implying that it was a task for the future, now to commence.

I did consider starting the book in 1911, when the national government first assumed direct administrative and legislative responsibility for some Aboriginal people (those in the Northern Territory). But that would still have left me with the problem of what to say about the new national government's stance towards the mastery of the continent in the period 1901-10, so well expressed by Deakin.

MJ: As you demonstrate time and again in the book, the projection of nationhood northwards, the idea that the continent can and should be mastered, is never completed. Notably, Indigenous and state sovereignties, based in different forms and practices of authority, continually challenge each other. What do you think accounts for that incompleteness or, to put it another way, why did Deakin's dream fail to become reality?

TR: There is an easily available explanation for the incompletion of Deakin's project: the relative inhospitality to settler colonisation of the climate and soils of much of the continent. When people migrate to Australia, they tend, in overwhelming proportions, to settle in the temperate zones and in the capital cities in particular, and that is still so. So if numerical preponderance over the indigenous people is a major determinant of the success of settler colonisation - its 'mastery' of a territory - then the settler colonisation of the Australian continent has been and continues to be a spatially uneven project. Incompleteness is evident in the fact that Australian governments still subsidise the colonisation of the north through tax concessions and other forms of public sector support, such as those effected by the Grants Commission.

What Deakin expected was that Aboriginal people would be outnumbered by colonising immigrants and that they would disappear into the settler population, and it seemed to him (in the first decade of Federation) that they were well on their way to doing so in Victoria and New South Wales. He also hoped and (I suppose) expected that administration and the rule of law would permeate every corner of the continent. This has come about. The 1966 Census demonstrated administrative mastery, in that the Commonwealth Bureau of Census and Statistics, with the help 
of missions, could for the first time exhaustively enumerate the entire Indigenous population. (In recent years, the Australian Bureau of Statistics has acknowledged that remote area enumeration is more difficult than it seemed in 1966, and it uses special methods. $)^{3}$

In jurisdiction, 'mastery' is a bit more complicated, as there is a lingering question of whether and how to take Aboriginal customary law into account in programs of 'justice investment', in the application of the criminal law and in formulating native title's 'bundle of rights'. I agree that the challenge of 'Indigenous difference' remains, though it is in the context of a huge asymmetry: Australian law can extinguish native title, but the reverse does not apply. The word 'mastered' is interesting. When the settler colonial state declared certain regions to be 'inviolable reserves', and when such reserves (despite never being totally 'inviolable') remained sites of enduring Indigenous enclaves and then became part of the Indigenous Land and Sea Estate, were such regions and their inhabitants 'mastered' or not? Such reserves and their successor legal regimes (the Indigenous Estate) were within the Crown's sovereign territory, as the militarisation of the remote regions in the Second World War and in the Cold War demonstrated, but the inhabitants have lived, and in thousands of cases continue to live, a distinct variation of 'the Australian way of life'.

So the continent has not been normatively integrated: pluralities remain. The argument for seeing that state of affairs as a lack of mastery or as incomplete mastery rests on a conception of the modern state as normatively ambitious - that is, as aspiring to ensure that high degree of cultural homogeneity that Ernest Gellner argued is characteristic of the modern nation-state. ${ }^{4}$ The 'Closing the Gap' strategy - with its appeal to norms of well-being established on the basis of comparison with non-Indigenous Australians - is a program of normative integration, of the 'mastery' of peoples and places most remote from the capital cities.

MJ: That process of 'normative integration' is depicted by other scholars as a process of ongoing settler colonialism. You have critiqued some theories of settler colonialism elsewhere. One of the points I've taken away from your critiques is your concern that there is a value judgement in the use of settler colonial theory that induces a kind of moral hesitation in historians. In your article on this topic in Australian Historical Studies, you advocated an 'impersonal analysis' that avoids taking what you call the position of a 'transcendant morality'. 5 I wonder if you would elaborate here on how you have cultivated this kind of approach in your work. I'm assuming that you are not arguing precisely for the 'noble dream' of objectivity but, rather, for the practising of a particular kind of historian's ethic; and one, moreover, that

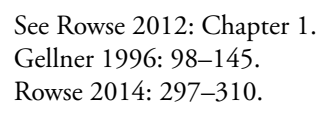


actually plays (or should play?) an important role in public discussion about Indigenous rights, settler state responsibilities, and so on, today? In other words, I guess it's a position that is neither that of activist or ivory-tower dweller?

TR: I am rather opposed to 'normative integration' if it is experienced more as pressure than as opportunity by the Indigenous Australians who are supposed to benefit from it. All opportunities create some pressures of course, and some of the choices facing Indigenous Australians are difficult to make because their consequences are difficult to foresee or because they are just intrinsically difficult. For example, it is good that there are opportunities for young people to commit to more years of formal education, but it is possible that this takes young people away from family and country, and also that it creates clashes of values and understandings between generations. Such dilemmas are unavoidable, but those in authority (including Indigenous authorities) should maximise the scope for choice - at the level of the individual and above - about whether and how to commit to the various futures on offer. That's my underlying value position, and it's hardly unique to me.

This leads me to the other part of your question: I have learned not to assume, in writing history, any conception of 'the Indigenous interest'. I assume that all humans have an interest in living as long as possible in dignified and happy ways, but among Indigenous Australians there is such a variety of starting points and visions and capacities that it is risky to generalise about what does or does not advance their interests. Nor do I find it possible to adopt a general view of the rights and responsibilities of non-Indigenous Australians and their governments. A responsible settler colony is always limited to ameliorative action, since the deed of colonisation is irreversible. Many ameliorative actions in the past now look morally ugly, but before pronouncing such a judgement, the historian should try to think him or herself into the shoes of those who did those things - that is, become aware of their knowledge, values, assumptions and instruments of authority. Empathy with narrated action is necessary to good description. The historian's investigative and imaginative effort should result in a sound, evidence-based decription of the actions, of the conjunctures in which they took place and of the consequences - intended and unintended. Moral judgement, applying the values of the historian, is then possible. Whether the historian proceeds to make the moral judgement explicit will be determined by the kind of relationship that the historian imagines he or she has with readers. I tend to imagine a readership that is diverse in its values and politics, and intelligent, and I rarely tell readers whether I think the actions I have described are consistent with my values. I could give anyone a list of things in Australia's past that I find deplorable, should they be interested. My list would overlap with many others'.

Finally, it could be said that the one value that the historian must not fail to honour is intellectual honesty: rendering the past as truthfully as the available evidence allows. The Uluru Declaration (May 2017) invited truthful historical scholarship as 
a basis for a more civil and just Australia. However, political identities are based as much on forgetting as on remembering, and so one still has to make a judgement about which truths to emphasise. With Emma Waterton, I have recently explored this issue, asking how the Native Mounted Police could figure in a revised Australian military heritage. ${ }^{6}$

MJ: In allowing for the space for engagement between reader and your text, you do run a risk of being misconstrued. I realise this is true to a degree for any writer or historian, but the risk is perhaps higher in a field such as this, because the field of Aboriginal history in Australia has been the subject of such acrimonious, polemicised and highly moralised public debate. Intellectual honesty, making up one's own mind, can open one up to the charge of being some kind of traitor, paradoxically even more so perhaps when refusing the role of history warrior. I was reflecting on this in reading your simply stated but surprisingly startling question that frames Chapter 4 of Indigenous and Other Australians Since 1901, 'did protection protect?'. As you point out in the opening of this chapter, this policy 'experimentation' had no clear method for assessing its success or failure. Moreover, the administrative processes measuring Aboriginal survival lacked, as you put it, an 'unquestionable database'. This administrative failure allowed for the perpetuation of 'dying race' stories, far beyond their demographic truthfulness (if a broad definition of 'Aboriginal' is used, you argue that demographic recovery was probably underway by the 1920s). Your answer to the simply stated question is, therefore, complex and demanding. I was wondering whether it asks (at least some) readers to rethink their assumptions at quite a deep level, thereby potentially risking their own moral positions and even identities. These present-day assumptions might be themselves artefacts of the absence of a countervailing story to demographic collapse. Is this something you thought about when writing the chapter?

TR: I think that you are right to say that people's political identities are at stake when they engage with narratives of Australia's colonial history. I recognise this because of the feelings that I have experienced in finding at least one of Keith Windschuttle's arguments persuasive: his critical review of Peter Read's account of New South Wales data on the 'Stolen Generations'. Windschuttle focused on whether the removals were permanent; the age at separation; the sex composition of those separated; their first destination; how many of the separated were 'orphan' or 'neglected' or without a male breadwinner in their household; whether we can infer an official intention that those removed would lose their Aboriginal identity; and the numbers removed. ${ }^{7}$ As Peter is a friend and Keith only a distant acquaintance (and as political identities are held in place partly by our ties of friendship) and as

Rowse and Waterton 2018.

Windschuttle 2009: 75-127. 
the Stolen Generations story has become exemplary of our opportunity to apologise for the heavy-handed and insensitive management of Indigenous Australians, I felt some discomfort in acknowledging Keith's review of the New South Wales archival evidence as compelling. ${ }^{8}$ I would like to see Peter's critical response to that part of Keith's book, as we would all learn from that debate. I recognise the pull of political identity also in the wariness of many of my collegues about giving the Native Mounted Police the attention that I think they require in the narrative of colonisation: the Native Mounted Police has the potential to shatter the narrative binary (in which Indigenous Australians are 'resistant' to non-Indigenous 'invasion') on which 'progressive' colonists like me draw. Political identities and friendships were also at stake in the debate about the Northern Territory 'Emergency Response' (the 'Intervention') - to which I have had a very ambivalent response. So yes, I am acutely aware of the emotional consequences and moral resonance of agreeing or disagreeing with this or that truth claim. This introspective debate about how to position myself has bothered me (but also strengthened me, I think) since Noel Pearson began to voice his critique of 'passive welfare' in 2000. Fortunately, some of the people with whom I discuss these things are friends of long standing, and this has given me confidence that the social fabric of my life is unlikely to be destroyed by a single disagreement. As well, in my academic world, I have many friends and acquaintances who reward me, with continuing respect and affection, for being frank in my uncertainties and unorthodoxies. We should not underestimate the importance of the emotional infrastructure of free inquiry.

Let me comment on the specific instance that you have raised: what you see as the 'complex and demanding' answer to the question 'Did protection protect?'. My position here is a very orthodox 'public policy' perspective. If public policy states an objective (as it should, in a rational world) then we are led to two questions: Do we have an instrument for measuring to what extent the objective was attained? And (if the answer is 'yes'): Was it attained? It is surprising that in the historiography of 'protection' there has been so little attention to one of the basic material impacts of 'protection': population recovery. In even conceiving this question, I owe a lot to Len Smith, the demographer and ANU colleague who I have worked with a little. ${ }^{9}$ Part of my answer also draws on his work, as my citations show - but also on the work of missions and those who have bothered to study their data. I hope that the chapter to which you refer will inspire some counterfactual history: could there have been a less regimented, patronising and racist set of instruments for arresting the decline of the Indigenous population? If there were such methods within reach, why did Australians not use them? Finally, I am dismayed by the online response by one reader of Philip Jones's review of my book in Australian Book

8 Rowse 2012: Chapter 5.

9 Smith 1980; Rowse and Smith 2010: 90-106; Smith et al. 2008: 533-55. 
Review. ${ }^{10}$ Commenting on his report that I had synthesised studies of protection's positive population impact, she wrote: 'Isn't this just another way of saying "at least European invaders didn't massacre them all'?' - implying that 'massacres' were the default manifestation of colonial authority! She then speculated that: 'Rowse's work sounds very much like an apologist interpretation of colonial policies, at least from this review of it'. I just hope she takes the trouble to read my book, so that she can make an informed judgement of the degree to which I am 'an apologist of colonial policies'. I certainly want to reserve to historians the possibility of judging some 'colonial policies' to have been better than others.

MJ: Your hope that this chapter will inspire some counterfactual history concerning the policy of protection (and other policies too, perhaps, including assimilation and even self-determination?) is striking to me. You know, no doubt, of the debate in New Zealand in the 1990s among historians about the Waitangi Tribunal's approach to and use of history. W.H. Oliver's essay 'The Future Behind Us: The Waitangi Tribunal's Retrospective Utopia' expressed considerable reservations about the construction of an alternative past in which previous governments were held to account for what they should have done, according to standards of the present, implying, Oliver thought, that governments could have behaved differently. He was concerned about the 'instrumental presentism' of the tribunal's history writing. ${ }^{11}$ What do you think of this argument? Is it equally a concern in the Australian context? Or does the absence of an institution like the Waitangi Tribunal here actually free up historians to produce more counterfactual or speculative histories about what colonial policy could have done?

TR: I don't know enough to comment on the scholarship generated by the Waitangi Tribunal's work, but I do agree strongly with the argument that the contingent capacities and instruments of colonial authorities are objects for historical inquiry. This would be so even if we did not use historical description as the basis for making moral judgements about past actions. Given that historians and readers DO consider the past through a morally evaluative lens, it is even more important that we try to understand, historically, the options that faced colonial authority at any specifiable moment in time. So the question: 'what could they have done?' is important, and answering it will give rise to counterfactual histories. I learned a lot by attempting the counterfactual: 'What if the Bruce-Page government had created a Model Aboriginal State?' ${ }^{12}$ I learned that the historian answering that question has to consider material features of colonial rule - such as transport, the size and composition of the public service, the availability of food stocks in remote regions, and so on. In Indigenous and Other Australians since 1901, I have tried to historicise

10 Jones 2018: 18-19. The reader's response can be found in the online edition of this issue.

11 Oliver 2001: 9-29.

12 Rowse 2006: 89-114. 
the capacities for colonial authority in my account of the changing relationships among colonial authorities (the civil state, the military state, the missions, the pastoralists) in the long, slow incorporation of the 'north' by the 'south'. Less prominent is the theme of Indigenous capacity - but it is there when I try to tell the stories of changing Aboriginal kinship and of severely limited formal education for Aboriginal children (producing a crippling literacy deficit). ${ }^{13}$

I'd like to address another aspect of your question: the relationship between counterfactuals and contemporary political/moral identities. Counterfactuals are often implicit. The biggest counterfactual of all, in critical histories of Australia's colonisation, is the question: 'How would Indigenous Australians have lived (and now be living) if Europeans had not colonised them?' When people make adverse moral judgement on the European colonisation of the Australian continent, they imply an answer to this question: Indigenous Australians then and now would have been much better off had they not been colonised. This answer is habitually presumed rather than set out as a plausible counterfactual story, and this presumption is possible because it is foundational to a progressive political identity that is generally anti-colonial. That is my political commitment too, but I would nonetheless like to see the counterfactual explored explicitly, rather than simply presumed. In contrast there are those (Geoffrey Blainey in his Boyer lectures is an example) who argue that while we must acknowledge and regret the immediate destructive impact of colonisation on Indigenous Australians, we should then take a long-term view in which it is possible to say that colonisation turned the Australian continent into a productive asset of benefit to the entire world and of benefit, in particular, to all who now live in Australia and share in its prosperity. ${ }^{14}$ The counterfactual in that argument is that the resources of the un-colonised continent would have remained under-used by a relatively small Aboriginal population. Again it is easy to see how that (usually implicit) counterfactual is foundational to a contemporary political identity: the perspective of John Howard's speeches in the 1990s in which he acknowledged harm done to Indigenous Australians while concluding that colonisation's moral balance-sheet was positive. It is not easy to make explicit these opposed counterfactuals, but they are there whenever our historical narratives take on an evaluative (morally, politically) meaning in public debate about the past and future of the nation.

Finally, let me answer the counterfactual that you have posed me: would debate about the colonial past in Australia be less 'free' were there a body similar to the Waitangi Tribunal in Australia? I find it hard to answer, as I have too little experience of the 'unfreedom' of historical controversies in New Zealand. One would think that

13 The reader interested in the topics kinship/sovereignty and education/literacy should consult the very detailed index in Rowse 2017: 495-504, under 'Aboriginal and Torres Strait Islander people'/'education/schooling' and /'kinship/governance'.

14 Blainey 2001. 
the most severe limitation on discussion in both Australia and New Zealand would be the difficulty of focusing the historical imagination on the Indigenous people on both sides of the Tasman who allied themselves with the Crown. ${ }^{15}$ However, on this matter, perhaps debate in New Zealand has been more free. My impression is that it has been easier to write freely about the multiple political affiliations of the Māori martial tradition than about the Aboriginal police tradition. I found Kynan Gentry's work on the Māori martial heritage interesting, just as I have been fascinated by the patriotism espoused by Apirana Ngata. ${ }^{16}$ Someone should write comparatively about Māori, Aboriginal and Torres Strait Islander 'patriotisms'. The Anglican Church and its missionary ancillaries will turn out to be a big part of that analysis, I conjecture.

MJ: That sounds like a great topic! What are some of the new directions in Indigenous and colonial history writing in Australia that you are most interested and excited about at the moment? What else do you think is not being examined that should be? You open up a number of new lines of inquiry in the latter part of the book; for instance, about the formation of an Indigenous middle class. Do you think these areas need to be further researched? And if so, how?

TR: Among the lines of inquiry that I think are very promising are those focused on individual lives of Indigenous Australians, including the recently initiated project led by Shino Konishi and other recent work that traces Indigenous 'mobilities' at the level of the individual. ${ }^{17}$ This work will reinforce our understanding of the variety of Indigenous adaptations and also the opportunism (in a non-pejorative sense) of any process of adaptation to what became an overwhelming alien presence. A limitation of taking the individual as the unit of analysis is that it may not convey collective responses at the level of the family, clan or 'tribe'. Such entities are poorly documented, but they are important as what they do is a big part of what we refer to as Indigenous 'sovereignty'.

This leads me to another theme of recent scholarship: the persistence of adapted and limited but real Indigenous jurisdiction under colonial conditions. This persistence is often more inferred than observed - that is, inferred from the attention paid to the limitations of colonial authority, as highlighted by scholars such as Heather Douglas, Mark Finnane, Anne Hunter and Lisa Ford. The de facto (from the colonists' point

15 Contributions by Michael Belgrave, Miranda Johnson and Amanda Nettelbeck in Carter and Nugent (2016) discuss how, in some colonies, indigenous regard for the British monarch went so far as to align colonised peoples militarily with British authority against other colonised peoples. As other contributors to this book show, the 'monarchism' of the colonised did not necessarily lead to such commitments of force. For speculation that Native Mounted Police in the Australian colonies may have been motivated in part by a sense of service to the Crown, see Rowse 2018: 1-23.

16 Gentry 2015.

17 See for example Carey and Lydon 2014; Shellam et al. 2016; and Standfield 2018. For information about the ANU-based project led by Shino Konishi see: history.cass.anu.edu.au/centres/ncb/research/indigenous-dictionaryaustralian-biography (accessed 18 December 2018). 
of view) persistence of Indigenous jurisdiction is a good theme for historical research, even if it is not easy to document the performances of Indigenous jurisdiction. Of course, in focusing on Indigenous jurisdiction, we will have to be careful not to idealise it: its norms and sanctions included phenomena alien to contemporary sensibilities.

Knowledge of colonial history can build analytically on existing scholarship by becoming more comparative. Some comparisons to make are of Australian colonies/ states and of regions within colonies/states, and here I'd remark in passing that we need to be on our guard about the continuing influence of the work of Patrick Wolfe whose knowledge of the case of 'Australia' (and his 'elimination/erasure' thesis) is based on what Patrick knew of Victoria. We now have sufficient scholarship on each colony/state to enable more secondary, comparative analysis within the case of 'Australia'. We are already starting to see systematic inter-colony comparison emerging from Griffith University's quantitative study of prosecutions. ${ }^{18}$ Comparisons within the CANZUS (Canada, Australia, New Zealand and the United States of America) are still too few, and I admire Alison Holland for teaching Australian colonial history in this comparative way at Macquarie. ${ }^{19}$ Your own work exemplifies the benefits of this comparison, Miranda. ${ }^{20}$ I plan to do a bit more of this myself - focusing on how 'reserves' were used.

It is important that in all these studies we do not equate 'colonial authority' with what the state did. One corollary of historicising state power is to throw attention towards such non-state colonial authorities as missions and employers. In the historiography of missions, Regina Ganter is leading the way with her Griffith University website and with her concise and penetrating The Contest for Aboriginal Souls: European Missionary Agendas in Australia (2018). ${ }^{21}$ Her work also reminds us that the ability to read non-English sources is necessary in much of the work on missions, and so that topic is unlikely to be crowded with Australia-based scholars, who are (myself included) lamentably monolingual.

The characteristic weakness of academic history is the relative absence of attention to the recent past. The recent past may be more difficult to document (though its oral history opportunities are greater) and it is more likely to be confronting of some political identities (that feel assured in their judgements of time-distant humanitarianism) because it is the past of our own lifespan. However, a strong grasp of the recent past is important as it informs current political debate. The period since 1973 includes experiments in Indigenous empowerment that have yet to be

18 'The Prosecution Project', prosecutionproject.griffith.edu.au (accessed 14 August 2018).

19 Holland 2018: 151-72.

20 Johnson 2016.

21 'German Missionaries in Australia', missionaries.griffith.edu.au (accessed 14 August 2018). 
studied historically. ${ }^{22}$ I'd like to see $\mathrm{PhD}$ projects on the history of the Aboriginal Arts Board (1973 - now), the Aboriginal Development Commission (1980-89) and Aboriginal and Torres Strait Islander Commission (ATSIC) (1990-2004). Much of the government records are now available, and many of the principal actors are still alive and (I hope) open to interview. In each of these agencies there were Indigenous intellectuals who had to conceive of themselves in historical terms - that is, as mediators of the opportunities of modernity to peoples empowered by the public affirmation of their traditions. That has to be a fascinating theme for research in the next 10 to 20 years.

Finally, I don't think we know nearly enough about the Indigenous experience of formal education and of print culture. The instructive comparison here is New Zealand where the early Māori-missionary interaction created a legacy of Māori literacy. Indigenous Australians are struggling to overcome a literacy gap. How did that gap come about? What efforts have been made and thwarted, by both sides, to equip Indigenous Australians with such basic instruments of self-determination?

\section{MJ: The field of Indigenous history here and elsewhere has been remarkably interdisciplinary. Is this something that you think can be further exploited?}

TR: There are two ways that historians can be interdisciplinary - one more difficult than the other. The relatively easy and not uncommon way is what we do when we write about the history of knowledge - its production and consumption. To do that, we have to increase our understanding of the knowledge traditions that we are writing about - for example, to write on the history of nursing and nurses may require some immersion in medical sciences, or to write a biography of a clergyman could well benefit from immersion in the theological questions that animated that person's life. No 'discipline' or intellectual tradition is foreign to historians, if they are willing to put in the work on such sources.

The other way that history can be interdisciplinary is when it makes the knowledgeobjects of other disciplines objects of its own inquiry. Insofar as these knowledgeobjects are constituted by concepts and methods that are specific to disciplines other than history - for example, demography, economics, anthropology, political science, linguistics, jurisprudence, philosophy, criminology - then the historian may find him or herself using the concepts and methods of those disciplines. Much of the most important work on Indigenous history has not been interdisciplinary in this second sense - at least, not in Australia. Indigenous history in Australia is still mostly revisionist national history (and I include my own work here). We have gone a long way in revising the account of the nation - taking seriously that it is a settler colonial society - by using sources and methods of analysis that were used in the orthodox account that we have revised. We have achieved much

22 A notable exception is Norman 2015. 
simply by asking new questions, but this did not require us to be interdisciplinary. The really important work of Henry Reynolds, Ann Curthoys, Andrew Markus, Ann McGrath, Bain Attwood, Heather Goodall, Richard Broome, Lyndall Ryan, Peter Biskup, Bob Reece, Anna Haebich and many others that I could mention has not been 'interdisciplinary', and in saying that I intend no criticism at all. The discipline that is most obviously relevant to Indigenous history is anthropology and yet few historians cite its concepts or use its methods. This is quite surprising since many Australian historians would say (and wear this as a badge of political honour) that they are committed to the idea that Indigenous sovereignty has never been ceded. Yet they rarely cite the ethnographic research that gives substance to the idea 'Indigenous sovereignty' - that is, research that describes (and sometimes historicises) Aboriginal and Torres Strait Islander modes of governance, including their customs of assigning people to land and regulating relationships between the sexes and between the generations. There is a rich literature on these topics, but few historians have tried to incorporate it into their accounts of the Indigenous responses to colonisation. Their training enables them to feel more comfortable historicising the colonists than the colonised. Indeed, some writing in the 'settler colonial studies' mould seems to make a virtue of not historicising the Indigenous a self-inflicted travesty of the 'politics of representation'.

The scholars in Indigenous history who have been 'interdisciplinary' in my second sense have mostly been anthropologists who have sought to historicise the findings of their ethnographies. Here I have in mind Diane Austin-Broos, Ian Keen, Howard and Frances Morphy, Peter Sutton, Jeremy Beckett, Francesca Merlan, Barry Morris, Gillian Cowlishaw, Nicolas Peterson, David Trigger, David Martin - to name only a few of the older guard, because there is a more recent generation whose opportunity to work both historically and ethnographically has come because of the evidentiary demands of native title work (Sally Babidge, Katie Glaskin, Eve Vincent - again to name only a few). There has also been historical investigation in the work of certain linguists (Patrick McConvell, Luise Hercus, and here I am even more hesitant to name exemplary names). I realise that I have answered your question with respect to Australia, and that your question might be answered differently by someone with a wider knowledge of 'Indigenous history'.

\section{MJ: And, finally, what's next for you, Tim?}

TR: I am currently working on four fronts. I want to write a paper about how 'reserves' were seen as a mechanism of 'protection' by nineteenth-century colonists. This will complement two other papers I have written on the nineteenth century: on the Native Mounted Police and on how pastoralists learned to practise some of the functions prescribed for 'protectors' (in press). ${ }^{23}$ Second, I am collaborating

23 See Rowse and Waterton 2018; Rowse 2018. 
with colleagues at Western Sydney University to write about the ways that the 'Indigenous/non-Indigenous binary' has become significant in the production and consumption of Australian culture. With Fred Myers and Laurie Bamblett, I am editing a collection on that theme. Third, I want to propose that it is now possible for historians to conceive the 'self-determination' era as a period in Australia's colonial history about which we can make generalisations, as we do already when we characterise the aims and mechanisms of the 'protection' and 'assimilation' eras. With Laura Rademaker, I am soon to host a workshop posing the question: 'How shall we write the history of Indigenous self-determination in Australia?' Laura Rademaker and I will edit a collection of papers from that workshop. Fourth, I'd like to continue to read Indigenous autobiographies and to annotate them in a systematic way to encourage others' use of them. I am falling behind in this project, but I look forward to the time when it is a work priority for me to read each autobiography as it appears and put the annotation online. On top of all that, I aspire to keep up with ethnographic writing about Indigenous Australia and to read in 'Global History' in the period since 1500 . And I like to grab the occasional opportunity to teach. I don't plan to write any more single-authored books.

\section{References}

Blainey, Geoffrey 2001, This Land Is All Horizons: Australian Fears and Visions, ABC Books, Sydney.

Carey, Jane and Jane Lydon (eds) 2014, Indigenous Networks: Mobility, Connections and Exchange, Routledge, New York and London. doi.org/10.4324/9781315766065.

Carter, Sarah and Maria Nugent (eds) 2016, Mistress of Everything: Queen Victoria in Indigenous Worlds, Manchester University Press, Manchester.

Ganter, Regina 2018, The Contest for Aboriginal Souls: European Missionary Agendas in Australia, ANU Press, Canberra.

Gellner, Ernest 1996, 'The coming of nationalism and its interpretation: The myths of nation and class', in Mapping the Nation, Gopal Balakrishnan (ed.), Verso, London and New York: 98-145.

Gentry, Kynan 2015, History, Heritage and Colonialism: Historical Consciousness, Britishness and Cultural Identity in New Zealand, 1870-1940, Manchester University Press, Manchester.

Holland, Alison 2018, 'Teaching and learning Indigenous history in a comparative and transnational frame: Lessons from the coalface', History Australia 15(1): 151-72.

Johnson, Miranda 2016, The Land Is Our History: Indigeneity, Law and the Settler State, Oxford University Press, New York. doi.org/10.1093/acprof:oso/9780190600020.001.0001. 
Jones, Philip 2018, “A single field of life”: A revisionist history of Aboriginal Australia', Australian Book Review March: 18-19.

Norman, Heidi 2015, What Do We Want? A Political History of Aboriginal Land Rights in New South Wales, Aboriginal Studies Press, Canberra.

Oliver W.H. 2001, 'The future behind us: The Waitangi Tribunal's retrospective utopia', in Histories Power and Loss: Uses of the Past - A New Zealand Commentary, Andrew Sharp and Paul McHugh (eds), Bridget Williams Books, Wellington, 9-29. doi.org/10.7810/ 9781877242205_1.

Rowse, Tim 2006, 'What if the Bruce-Page Government had created a model Aboriginal state?', in What If? Australian History as It Might Have Been, Stuart Macintyre and Sean Scalmer (eds), Melbourne University Press, Melbourne, 89-114.

Rowse, Tim 2012, Rethinking Social Justice: From 'Peoples' to 'Populations, Aboriginal Studies Press, Canberra.

Rowse, Tim 2014, 'Indigenous heterogeneity', Australian Historical Studies 45(3): 297-310. doi.org/10.1080/1031461X.2014.946523.

Rowse, Tim 2017, Indigenous and Other Australians Since 1901, UNSW Press, Sydney.

Rowse, Tim 2018, 'The moral world of the Native Mounted Police', Law and History 5(1): $1-23$.

Rowse, Tim and Len Smith 2010, 'The limits of "elimination" in the politics of population', Australian Historical Studies 41(1): 90-106. doi.org/10.1080/10314610903317598.

Rowse, Tim and Emma Waterton 2018, "The "difficult heritage" of the Native Mounted Police', Memory Studies, journals.sagepub.com/doi/10.1177/1750698018766385 (online publication only), accessed 29 July 2018.

Shellam, Tiffany, Maria Nugent, Shino Konishi and Allison Cadzow (eds) 2016, Brokers and Boundaries: Colonial Exploration in Indigenous Territory, ANU Press, Canberra.

Smith, L.R. 1980, The Aboriginal Population of Australia, Australian National University Press, Canberra.

Smith, Leonard, Janet McCalman, Ian Anderson, S. Smith, Julie Evans, Gavan McCarthy and J. Beer 2008, 'Fractional identities: The political arithmetic of Aboriginal Victorians', Journal of Interdisciplinary History 38(4): 533-55.

Standfield, Rachel (ed.) 2018, Indigenous Mobilities: Across and Beyond the Antipodes, ANU Press, Canberra, 2018. doi.org/10.22459/IM.06.2018.

Windschuttle, Keith 2009, The Fabrication of Australian History: Volume Three the Stolen Generations, Macleay Press, Sydney, 75-127. 
This text is taken from Aboriginal History, Volume 42, 2018, edited by Ingereth Macfarlane, published 2018 by ANU Press, The Australian National University, Canberra, Australia.

doi.org/10.22459/AH.42.2018.06 